\section{LA PEDANTOCRACIA: EL ROSTRO MODERNO DEL DESPOTISMO. LA MIRADA DE JOHN STUART MILL ${ }^{1}$}

THE PEDANTOCRACY: THE MODERN FACE OF DESPOTISM. JOHN STUART MILL'S VISION

MARÍA POLLITZER .

María Pollitzer es Licenciada en Historia y Doctora en Ciencias Políticas por la Universidad Católica Argentina (UCA).

\section{Resumen}

El objetivo del artículo es identificar y precisar los argumentos con los cuales John Stuart Mill construye su crítica a la pedantocracia, entendida como uno de los rostros con los cuales se presenta el despotismo en las sociedades «modernas» $y$ "civilizadas». El término pedantocracia fue acuñado por Mill a comienzos de la década de 1840 para referirse a un peligro que, en su opinión, pocos percibían. Como ocurre con otras ideas-eje de su pensamiento, su reflexión sobre esta problemática se articula en torno al diálogo mantenido con pensadores provenientes del liberalismo continental (Tocqueville), del socialismo saint simoniano (d'Eichthal y Duveyrier), del positivismo (Comte) y de las filas románticas inglesas (Coleridge). Asimismo, es reflejo de su recepción de las obras de Platón y del renovado interés que suscitó la democracia ateniense a mediados del siglo XIX gracias a las obras de G. Grote.
Alicia Moreau de Justo 1500, C1107AAZ, Ciudad de Buenos Aires.

E-mail: maria_pollitzer@hotmail.com

\section{Abstract}

The article's aim is to identify and clarify the arguments with which John Stuart Mill builds his critique of pedantocracy, understood as one of the faces with which despotism presents itself in «modern» and "civilized» societies. The term pedantocracy was coined by Mill in the early 1840 s to refer to a danger that, in his opinion, only few people perceived. As it happens with other key ideas of his thought, his reflections on this issue revolve around the dialogue maintained with thinkers from continental liberalism (Tocqueville), Saint-Simonian socialism (d'Eichthal and Duveyrier), positivism (Comte) and the English romanticism (Coleridge). It also reflects his reception of the works of Plato and the renewed interest shown in Athenian democracy in the mid-nineteenth century, especially through the works of G. Grote.

\footnotetext{
${ }^{1}$ Una versión preliminar de este artículo fue presentado en el XII Congreso Nacional de Ciencia Política, Mendoza, 12-15 de agosto de 2015.
} 